\title{
Algılanan Yönetici Desteğinin Psikolojik Sözleşmenin İçeriği ve Yerine Getirilmesi Üzerindeki Etkileri
}

\author{
Merve GERÇEK ${ }^{*}$ Sevgi ELMAS-ATAY*
}

Öz

Psikolojik sözleşme, işveren ve çalışan arasındaki istihdam ilişskisindeki dinamikleri açıklamak için kullanılan bir kavramdır. Psikolojik sözleșme, çalıșanların örgütsel yükümlülüklere ilişkin öznel algılarını ifade etmektedir. Örgütsel politikalar, prosedürler, uygulamalar ve yöneticiler, çalışanlardan beklenenler ile örgütün çalıșana sağlamakla yükümlü bulunduğu unsurlar hakkında bilgi aktarımı sağlamaktadır. Özellikle her kademeden yöneticinin, çalışanların örgüte yönelik algıları üzerinde etkin rol oynadığı varsayılmaktadır. Yöneticilerin, örgüt temsilcisi olarak psikolojik sözleşmenin oluşumu ve sürdürülmesi üzerinde etkili olduğu öne sürülmektedir. Bu çalışmanın amacı, algılanan yönetici desteğinin psikolojik sözleșmenin içeriği ve yerine getirilme düzeyi üzerindeki etkilerinin belirlenmesidir. Özel sektörde çalıșan 224 beyaz yakalı katılımcı ile yapılan çalışmada, yönetici desteğinin psikolojik sözleşme unsurlarının örgüt tarafından vaat edilme düzeyini olumlu yönde etkilediği görülmüştür. Ayrıca, yönetici desteği arttıkça, psikolojik sözleşmenin yerine getirilme düzeyinin de arttığı belirlenmiştir.

Anahtar Kelimeler: Psikolojik sözleşme, Algılanan yönetici desteği, Psikolojik sözleşmenin yerine getirilmesi, Özel sektör, Türkiye

JEL Kodları: M11

\section{A Study on the Effects of Perceived Supervisory Support on Psychological Contract Content and Fulfillment}

\section{Abstract}

The psychological contract is a concept used to explain the dynamics of the employment relationship between the employer and the employee. The psychological contract refers to the subjective perceptions of employees regarding organizational obligations. Organizational policies, procedures, practices, and managers convey information about what is expected from the employees and what the organization is obliged to provide to employees. It is assumed that managers from all levels play an active role in employees' perceptions of the organizational procedures. The supervisors are claimed to be effective in the formation and progression of the psychological contract as a representative of the organization. The aim of this study is to determine the effects of the perceived supervisory support on the content and fulfillment of the psychological

\footnotetext{
Özgün Araştırma Makalesi (Original Research Article)

Geliş/Received: 24.03 .2020

Kabul/Accepted: 06.04 .2021

DOI: https://dx.doi.org/10.17336/igusbd.701535

* Dr. Öğr. Üyesi, Kocaeli Üniversitesi, Hereke Ömer İsmet Uzunyol MYO, Yönetim ve Organizasyon Bölümü, İnsan Kaynakları Yönetimi Programı, Kocaeli, Türkiye,

E-posta: merve.gercek@kocaeli.edu.tr ORCID https://orcid.org/0000-0002-7076-8192

** Arş. Gör. Dr., İstanbul Üniversitesi, İşletme Fakültesi, İnsan Kaynakları Yönetimi Anabilim Dalı, İstanbul, Türkiye, E-posta: sevgielmas@istanbul.edu.tr ORCID https://orcid.org/0000-0002-2238$\underline{4979}$
} 
contract. In the study conducted with 224 white-collar participants working in the private sector, it was observed that the supervisory support had a positive effect on the psychological contract content. In addition, it was determined that as the supervisory support increased, the level of fulfillment of the psychological contract increased as well.

Keywords: Psychological contract, Perceived supervisory support, Psychological contract fulfillment, Private sector, Turkey

JEL Classification: M11

\section{Giriş}

Psikolojik sözleşme kavramı yasal sözleșmelere atıfta bulunan bir metafordur. Son 30 yıldır çalışan tutum ve davranışları üzerindeki olumlu ve olumsuz etkileri tartışılan bu kavram, istihdam ilişkilerinde açıklayıcı bir çerçeve olarak kabul edilmektedir (Guest ve Conway, 2002). Psikolojik sözleșme genel olarak, çalışanların örgütün kendisine sağlamakla yükümlü olduğu unsurlara yönelik beklentilerini ve bu beklentilerin karşılanma düzeylerini kapsamaktadır. Eğitim ve geliştirme olanakları, kariyer fırsatları, performansa dayalı ücret, iş ve yaşam dengesi, adil uygulamalar ve benzeri konuları içine alan psikolojik sözleşme, yerine getirilmemesi durumunda örgüte bağlılığı azaltarak, işten ayrılma niyetinde artışa yol açabilmektedir.

Psikolojik sözleşmenin oluşumunda ve sürdürülmesinde örgütsel uygulamalar kadar yöneticilerin de önemli bir yeri bulunmaktadır. Bunun başlıca sebebi, psikolojik sözleşmenin içeriğini oluşturan unsurların örgüt tarafından çalışanlara yansıtılmasında yöneticilerin birer aracı olmasıdır (McDermott, Conway, Rousseau ve Flood, 2013). Daha açık bir ifade ile yöneticiler, çalışanlara ilişkin karar alıcı konumda bulundukları için çalışanların algılarını etkilemektedirler.

Örgütler, belirli amaçlara ulaşabilmek için bir araya gelmiş olan insan toplulukları olarak ele alındığında, bu amaçlara erişme yolunda özellikle çalışan düzeyinde ele alınan önemli bir değişken de yönetici desteğidir. Yönetici desteği, tarafların karşılıklı çıkar elde etmeye yönelik olarak ilişki geliştirdiği varsayımına dayanan Sosyal Takas Kuramı'ndan (Blau, 1964; Homans, 1974) beslenen örgütsel destek kavramının önemli bir boyutu olarak ele alınmaktadır. Örgütsel destek, temel olarak çalışanların üyesi bulundukları örgüt tarafından değerli olarak görüldüklerini ve örgüte katkılarına verilen öneme ilişkin inançlarını ifade etmektedir (Rhoades ve Eisenberger, 2002). Bir başka deyişle, örgütsel destek örgütün çalışana nasıl davrandığı ile ilgilidir. Örgütün çalışana olan yaklaşımının belirleyicilerinden birisi de, örgütsel uygulamaların ve mesajların ileticisi olan yöneticilerdir. Örgütsel yönlendirme sürecinde net bir anlayıș bulunmaması durumunda, çalışanlara yön gösteren yöneticiler olmaktadır (Ramus ve Steger, 2000). Bu bağlamda yönetici desteği, yöneticilerin çalışanların örgüte katkıları ve onların iyi oluş halleri ile ilgilenme düzeyidir. Yönetici desteğinin çalışan bağlılığı, örgütsel adalet algısı gibi olumlu çalışan tutumlarının yanında, işletmeye dolaylı veya doğrudan maliyet yükleyen işe devamsızlık, işgücü devir oranı ve iş stresi gibi çalışan çıktılarıyla ilişki içinde olduğu görülmüştür (Aydın Göktepe, 2016: 12).

Örgüt tarafından gönderilen mesajlara bağlı olarak çalışanların zihinlerinde oluşan şemalar psikolojik sözleşmenin içeriğini oluşturmaktadır. Daha açık bir ifade ile psikolojik sözleşmenin içeriği, örgütsel politikalar ve bunların yöneticiler tarafından uygulamaya geçirilme şekline bağlı olarak bazı çalışma koşullarının açı veya örtük şekilde çalışana vaat edilme düzeyidir. Söz konusu vaatlerin çalışanlara sunulma düzeyi ise psikolojik sözleşmenin yerine getirilme düzeyi olarak ifade edilebilir. Psikolojik sözleşmenin oluşumunda ve yerine getirilmesinde çalışanların nasıl bir zihinsel şema oluşturacağının, yöneticilerin onların katkılarını değerlendirme tarzına bağlı olduğu öne 
sürülmektedir. Bu bağlamda yöneticilerin, birer örgüt temsilcisi olarak hem psikolojik sözleşmenin içeriği hem de yerine getirilme düzeyi üzerinde etkili olacağı beklenmektedir.

\section{KURAMSAL ARKA PLAN}

\subsection{Psikolojik Sözleşmelerin İçeriği ve Yerine Getirilmesi}

İşveren ve işgören arasındaki iş ilişkisinin genellikle yazılı bir sözleşmenin imzalanmasıyla başladığı kabul edilmektedir. Yazılı iş sözleşmeleri, hukuki bağlayıcılığı bulunan, çalışma koşullarının açık bir şekilde ifade edildiği somut yapılardır. Buna karşılık psikolojik sözleşmeler, yazılı sözleşmeler gibi hukuki bağlayıcılığı bulunmayan ancak sonuçları bakımından işvereni ve örgütü yakından ilgilendiren bir kavramdır.

Psikolojik sözleșme kavramına ilk olarak Argyris'in (1960) çalışmasında rastlanılmıştır. Yazarın çalışmasında kelime grubu olarak "psikolojik sözleşme" kullanılmamakla birlikte, üretim bölümünde çalışan ustabaşılar ve işçiler arasında üzerinde konuşulmamıș bazı kuralların bulunduğu vurgulanmıștır. Daha sonraları Schein (1980), Kotter (1973), Portwood ve Miller (1976) eserlerinde "psikolojik sözleşme" kavramına birer tanım getirmişlerdir. Psikolojik sözleşme kavramının gelişimindeki en önemli dönüm noktası, Rousseau'nun $(1989,1990)$ söz konusu kavramın sınırlarını çizmeye çalışan çalışması olmuştur. Rousseau'ya göre psikolojik sözleșme, bireyin diğer bir birey ya da taraf arasındaki karşılıklı değişim anlaşmasının şart ve koşullarına ilişsin inancidır.

Psikolojik sözleșme, yasal sözleșmeye atıfta bulunan bir olgudur. İki sözleșme türü de işveren ve çalışan arasında var olmakla birlikte, psikolojik sözleşmeler yasal sözleşmelerin birer psikolojik yansıması olarak düşünülmektedir. Psikolojik sözleşmeler bireysel inançlara dayandığı için kişiye özel ve oldukça değisşkendir. Rousseau'nun (1989) tanımı, psikolojik sözleşmeleri yalnızca çalışanın zihnindeki bir olgu olarak sınırladığı için sistematik olarak değerlendirilmesini kolaylaştırsa da kendisinden sonraki çalışmalarda bu durum eleștirilmiștir. Guest ve Conway (2002), psikolojik sözleșmenin iki taraflı bir olgu olduğunun ve yalnızca çalışanın gözünden incelenmesinin eksik kalacağının altını çizmişlerdir. Psikolojik sözleşmenin karşılıklılık ilkesine dayandığına inanan yazarlar, sözleşmenin unsurlarının nasıl algılandığını hem işveren veya yöneticiler hem de çalışanlar açısından değerlendirerek karşılaștırma yapmayı daha uygun bulmuşlardır (Örn. Coyle-Shapiro ve Kessler, 2002). Benzer şekilde yönetsel açıdan psikolojik sözleşmenin değerlendirildiği çalışmalar da bulunmaktadır (Cable, 2010; Gerçek, 2018).

Psikolojik sözleşmenin oluşumunda normatif beklentiler, örgütsel hedeflere bağlı çeşitli mesajlar ve işverenin vaatleri rol oynamaktadır (Rousseau, Hansen ve Tomprou, 2018). Psikolojik sözleşmeyi oluşturan unsurlar genel olarak çalışan yükümlülükleri ve örgütsel yükümlülükler olarak iki sınıfa ayrılmaktadır. Çalıșan yükümlülükleri, çalışanın örgüte sunmakla yükümlü olduğu ve yerine getirmeyi vaat ettiği yükümlülüklerdir. Fazla mesai karşılığında ücret beklentisi olmaması, işverene sadakat, gönüllü davranıșlar, nakil/transfer kabulü, kabul edilebilir performans, örgütsel kaynakların korunması gibi unsurlar çalışan yükümlülükleri arasındadır (Rousseau, 1989; Robinson, 1996). Örgütsel yükümlülükler ise, örgütün çalışana sunmayı vaat ettiği ve çalışanın da beklenti içinde bulunduğu unsurları içermektedir. Sıklıkla karşılaşılan örgütsel yükümlülükler arasında; kariyer fırsatları, iyi bir ücret paketi, eğitim olanakları, iş güvencesi, destek ve benzeri bulunmaktadır. Psikolojik sözleşmenin içeriğini oluşturan yükümlülükler, örgütsel bağlamda farklılık gösterebilmektedir. Ayrıca, örgütsel yükümlülükleri psikolojik sözleşmenin bir parçası olarak varsayabilmek için örgütün bu yükümlülüklerden birisini açık veya örtük şekilde vaat etmiş olması gerekmektedir. Örgütsel bağlamda izine rastlanılmayan bir unsurun çalışan tarafından bekleniyor olması psikolojik sözleşme 
bakımından yükümlülük olarak sayılmamaktadır. Psikolojik sözleşme unsurlarının yalnızca iş ilişkisinin ekonomik yönüne odaklanan boyutu etkileşimsel, sadakat, bağlılık ve adanma gibi sosyal yönünü vurgulayan boyutu ise ilişkisel sözleşme olarak ifade edilmektedir (Rousseau, 1990).

Psikolojik sözleşmenin oluşumuna yönelik oluşturulan kavramsal modellerde, örgütsel etmenlerin bu süreçte önemli rol oynadığı önerilmiştir (Petersitzke, 2009). İstihdam ilişkileri, örgütsel istihdam stratejileri, insan kaynakları (İK) uygulamaları ve liderlik gibi etmenlere bağlı olarak şekillenmektedir. Dolayısıyla psikolojik sözleşmenin içeriğini oluşturan algılanan yükümlülükler, söz konusu değişkenler çerçevesinde oluşmaktadır. Rousseau'ya (1995) göre psikolojik sözleşmenin oluşumunda birincil ve ikincil sözleşme oluşturucular bulunmaktadır. Birincil sözleşme oluşturucular; üst yönetim, hat yönetimi, İK uzmanları, takım üyeleri ve mentorlardır. İkincil sözleșme oluşturucular ise İK uygulamaları, el kitapçıkları ve görev tanımları gibi çalışanlardan neler beklendiğini ve örgütün sağlayacağı olanaklar hakkında bilgi sağlayan kaynaklardır. Yöneticiler etkileşimsel ve gözlemsel sözleşme oluşturuculardır. Bir başka deyişle yöneticiler, çalışanlarla iletişime geçerek örgütü temsil etmekte ve çalışan davranışlarını izleyerek davranışlarını yönlendiren aktörlerdir. Ayrıca yöneticiler, örgütsel politikaları uygulayan ve çalışanların gözünde örgütsel vaatlerde bulunan kişilerdir. Hat yöneticileri, performans değerlendirme, eğitim ve geliștirme uygulamaları, çalışanlara ilişkin kariyer kararları gibi süreçlerde etkin rol oynamaktadırlar. Dolayısıyla, çalışanların psikolojik sözleşmenin yerine getirilme düzeyini ilk üstleriyle ilişkilendirdiği görülmüştür (McDermot vd., 2013).

Psikolojik sözleşmenin yerine getirilmesi, çalışanlar açısından örgütsel yükümlülüklerin yerine getirilmesidir (Robinson ve Rousseau, 1994). Eğitim ve geliştirme, ücret, terfi, iş güvencesi, sorumluluk ve ikili ilişkilerde vaat edilen bir unsurun çalışana verilmemesi durumunda psikolojik sözleşmenin yerine getirilmediği söylenmektedir. Psikolojik sözleșmenin yerine getirilmemesi, yasal sözleșme gibi hukuki sonuçlar doğurmamakla birlikte çalışanın işverene olan güvenini sarsmaktadır (Robinson, 1996). Buna bağlı olarak, çalıșanın olumsuz tutum ve davranışlar geliștirme eğilimi artmaktadır. Turnley ve Feldman (1999), psikolojik sözleșmenin yerine getirilme düzeyinin, örgüt kültürü, yönetici davranışları ve çalışan beklentilerinin etkisi altında ortaya çıktığını ifade etmişlerdir. Daha açık bir ifadeyle, örgütsel süreçlerde ve yöneticilerin davranışsal motiflerindeki tutarsızlıklar çalışanlarda olumsuz algılara yol açabilmektedir.

Psikolojik sözleşmenin yerine getirilmemesi, çalışanlar açısından karşılanmayan beklentilerin varlığına işaret ederek, eşitsizlik algılandığının ve örgütsel güvenin azaldığının göstergesi olabilmektedir (Sturges, Guest ve Conway, 2005). Psikolojik sözleşmenin yerine getirilmemesi, çalışanların iyi oluş halinin azalmasına, iș ve örgüte karşı olumsuz tutumlar geliştirmesine, iş tatminsizliği, düşük bağlılık, düşük iş performansı gösterme ve işten ayrılma niyetinde artış gibi sonuçlara yol açması açısından önemlidir (Conway ve Briner, 2006; Salin ve Notelaers, 2017).

\subsection{Yönetici Desteği}

Örgütsel Destek Kuramı, çalışanların sosyo-duygusal ihtiyaçlarını karşılamak için, üyesi oldukları örgütün onların katkılarına ve iyi oluşlarına ne ölçüde değer verdiğine ilişkin genel inançlar geliştirdiğini öne sürmektedir (Eisenberger, Huntingyon, Hutchison ve Sowa, 1986). Bu kuramın temel dayanağl, çalışanların örgütü bir bütün olarak gördükleri varsayımıdır. Ancak yöneticiler, performans değerlendirme görüşmeleri ve performansa dayalı ücretin belirlenmesi gibi bireysel düzeydeki kararlarda daha etkin rol oynamaktadırlar. Örgütün çalışanları değerlendirmesinde birer aracı olarak görev yapan 
yöneticiler sayesinde algılanan örgütsel desteğin yöneticiler üzerinden ortaya çıktığı düşünülebilir. Bunun sonucu olarak, yöneticinin desteğinin, çalışanın genel örgüt desteğine ilişkin algısı üzerinde güçlü bir etkisi olduğu belirtilmektedir (Shanock ve Eisenberger, 2006).

Yönetici desteği bir üstün, astının örgüte katkılarına ve iyi oluş haline yönelik ilgili olması ve yapıcı geri bildirimlerde bulunması olarak tanımlanmaktadır (Rhoades ve Eisenberger, 2001). Bu doğrultuda yönetici desteği, örgütteki objektif durumdan ziyade bireysel bir algılayış biçimidir. Yöneticilerin, çalışanlarla etkileşim düzeyinin oldukça yüksek olması ve kariyer, eğitim, performans ve ücret gibi kararlarda doğrudan etkili olması nedeniyle çalışanlara yönelik tutum ve davranışları, bireysel ve örgütsel sonuçlar üzerinde önemli sonuçlar doğurmaktadır.

Yapılan araştırmalarda örgütsel destek ve yöneticinin desteği arttıkça, çalışanların, üstlerinin kariyer hedeflerine ulaşmak konusunda bir zorunluluk hissettiklerini düşündükleri ve işten ayrılma niyetinde azalma olduğu ortaya çıkmıștır (Maertz, Griffeth, Campbell ve Allen, 2007; Eisenberger, Stinglehaumber, Vandenberghe, Sucharski ve Rhoades, 2012). Yöneticilerinden kariyerlerine ilişkin destek gördüklerini hisseden çalışanların iş tatminleri artmakta (Alkhateri, Abuelhassan, Khalifa, Nusari ve Ameen, 2018), kurumlarına olan bağlılıkları de yine artış göstermektedir (Vandenberghe, Panaccio, Bentein, Mignonac, Roussel ve Ayed, 2019). Bunlara ek olarak, algilanan yönetici desteği arttıkça çalışanların iş stresi düzeylerinde azalma ve performans düzeylerinde artış gözlenmiştir (Rhoades ve Eisenberger, 2002; Viswesvaran, Sanchez ve Fisher, 1999). Benzer şekilde, çalışanların yönetici desteğini hissettiği durumlarda, olumsuz iş yeri davranışlarının artacağı ve örgütsel performansın düșeceği öne sürülmektedir (Shoss, Eisenberger, Restubog ve Zagenczyk, 2013).

Çalışanlar yöneticilerinin destekleyici bir tutum sergilediğini düşündüklerinde, yöneticilerini ihtiyaçlarının neler olduğunu bilen ve bu ihtiyaçları sağlayan kişiler olarak tanımlamaktadır. Dolayısıyla çalışan ile yönetici arasındaki iş ilişkisi olumlu olarak algılandığında, çalışanların zihninde yönetici desteğine ilişkin olumlu algılar ortaya çıkmaktadır. Bu anlayış bir bakıma Sosyal Takas Kuramı çerçevesinde de ele alınabilir (Aydın Göktepe, 2016: 13). Sosyal Takas Kuramı (Blau, 1964; Homans, 1974), çalışanların motivasyon düzeylerini ve bu düzeylerin örgütsel hedeflere ulaşılmasıyla nasıl ilişkili olduğunun önemini vurgulamaktadır. Bu yaklașım, çalışanların ve işverenler arasındaki karşılıklı yükümlülükler dâhilinde belirli faaliyetleri yürütmek için çalışanların nasıl harekete geçtiklerini açılamaya çalışmaktadır. Kendilerine vaat edilen kaynaklara ve hem örgüt tarafından iletilen hem de karşılıklılık normuna dayanan yükümlülüklere bağlı olarak, çalışanlar kuruluşla psikolojik bir sözleşme oluşturmaktadır. Dolayısıyla Psikolojik Sözleşme Kuramı örgütün vaatlerini, çalışanların memnuniyetsizliğinin ve düşük performansının kilit belirleyicisi olarak algılamamasındaki etkinin altını çizmektedir. Hem Örgütsel Destek Kuramı hem de Psikolojik Sözleșme Kuramı, çalışanlara davranış şeklini çalışan-örgüt ilişkisinin geliştirilmesi ve sürdürülmesi için önemli olacak bir faktör olarak değerlendirmiştir (Aselage ve Eisenberger, 2003).

Psikolojik sözleşmelerin örgütsel özdeşleşme üzerindeki etkisinde örgüt desteğinin kısmi aracı olarak görev yaptığına ilişkin bulgulara rastlanmıştır (Zagenczyk, Gibney, Few ve Scott, 2011). Psikolojik sözleşmenin oluşumunda örgüt temsilcisi olarak düşünülen ve sözleşme oluşturucu olarak kabul edilen yöneticilerin yanı sıra mentorlar ve rol modellerinin de psikolojik sözleşmenin yerine getirilme düzeyini olumlu yönde azalttığı belirlenmiştir (Zagenczyk, Gibney, Kiewitz ve Restuborg, 2009). Yapılan çalışmalarda psikolojik sözleşmenin yerine getirilmesinin örgüt desteği ile olumlu yönde ilişkili olduğu görülmüştür (Bhatnagar, 2014; Karagonlar, Eisenberger, Aselege, 2016). Bu bilgiler ışığında aşağıdaki hipotezlerin sınanması amaçlanmıştır: 
Hipotez 1: Algılanan yönetici desteği, psikolojik sözleșme içeriğinin örgüt tarafından vaat edilme düzeyini olumlu yönde etkilemektedir.

Hipotez 2: Algılanan yönetici desteği, psikolojik sözleşmenin yerine getirilme düzeyini olumlu yönde etkilemektedir.

\section{YÖNTEM}

\subsection{Araştırmanın Önemi ve Kapsamı}

Bu çalışmada algılanan yönetici desteğinin psikolojik sözleşmenin içeriği ve yerine getirilme düzeyi üzerindeki etkileri araştırılmıştır. Yöneticiler, psikolojik sözleşmenin oluşumunda örgüt temsilcisi ve sözleşme oluşturucu olarak etkin rol oynayan birer aktör olarak kabul edilmektedir. Bu varsayım doğrultusunda yöneticilerin çalışana desteğinin, örgütsel yükümlülüklerin çalışanlara aktarılmasında olumlu etki yaratacağı öngörülmüştür. Benzer şekilde, yönetici desteğinin örgütsel yükümlülüklerin yerine getirilmesinde olumlu katkıda bulunacağı beklenmektedir. Araștırmanın örneklemini özel sektörde çalışan \%50,9'u kadın, \%49,1'i erkeklerden oluşan 224 beyaz yakalı çalıșan oluşturmaktadır. Örnekleme yöntemi olarak tesadüfi olmayan örnekleme yöntemlerinden zaman ve maliyet kısıtları göz önünde bulundurularak kolayda örnekleme yöntemi seçilmiştir.

\subsection{Araştırmanın Veri Toplama Araçları ve Analiz Yöntemi}

Araştırmada veri toplama aracı olarak yönetici, psikolojik sözleșmenin içeriği ve yerine getirilmesine ilişkin ölçeklerin yer aldığı anket formu kullanılmıştır. Ölçüm araçlarının özellikleri aşağıda belirtilmiştir.

Yönetici Desteği Ölçeği: Algılanan yönetici desteği düzeyini belirleyebilmek için Greenhaus, Parasuraman ve Wormley (1990) tarafından kullanılan ölçüm aracından yararlanılmıștır. Çalışanlara, yöneticilerinin kendilerine iş yaşamlarına ilişkin çeşitli konularda (kariyer, performans vb.) destek olup olmadıkları sorulmuştur. Yönetici desteği, 9 maddeden oluşan 5’li Likert ölçek üzerinde (1: "Kesinlikle katılmıyorum"; 5: "Kesinlikle katılıyorum") değerlendirilmiştir. Ölçekten elde edilen puan arttıkça, çalışanların yöneticilerinden gördükleri destek düzeyinin artmış olduğu sonucuna varılmaktadır.

Psikolojik Sözleşme İçeriği Ölçeği: Psikolojik sözleşmenin içeriğinin değerlendirilmesi için Guest ve Conway'in (2002) oluşturduğu ölçüm aracı kullanılmıştır. Yazarlar, nitel veri toplama yöntemine dayanarak bir araya getirdikleri 13 yükümlülüğün "örgüt tarafından vaat edilme düzeyini" 4'lü likert ölçek (1: "Hiç vaatte bulunmamıștır"; 4: "Yazılı veya sözlü bir şekilde vaatte bulunulmuştur") üzerinden değerlendirmiştir. Ölçekten elde edilen puan yükseldikçe, eğitim, terfi, ücret vb. konulardaki vaatlerin daha açık bir şekilde ifade edilmiş olduğu ortaya çıkmaktadır.

Psikolojik Sözleşmenin Yerine Getirilmesi Ölçeği: Guest ve Conway'in (2002) kullandığı 13 maddelik, 4'lü likert (1: "Hiç sağlamamaktadır."; 4: "Beklentimin üzerinde sağlamaktadır") ölçek kullanılmıştır. Çalışanlara "örgütsel yükümlülüklerin yerine getirilme düzeyi" sorulmuştur. Ölçekten elde edilen puan arttıkça, psikolojik sözleşmenin yerine getirilme düzeyinin artmış olduğu ortaya çıkmaktadır.

Araştırma hipotezlerinin sınanmasında SPSS 21.0 yazılımı ile Pearson Korelasyon Analizi ve basit doğrusal regresyon analizinden yararlanılmıştır. 


\section{BULGULAR}

\subsection{Tanımlayıcı İstatistikler}

Tablo 1'de görüldügü üzere, elde edilen verilere göre katılımcıların "Psikolojik Sözleşmenin İçeriği Ölçeği"nden aldıkları puanların ortalaması 2,31; "Psikolojik Sözleşmenin Yerine Getirilmesi Ölçeği"nden aldıkları puanların ortalaması ise 2,28'dir. Psikolojik sözleşmenin içeriğini oluşturan unsurların vaat edilme düzeyi ve söz konusu vaatlerin yerine getirilme düzeylerinin ortalamasının birbirine yakın ve orta düzeyde olduğu görülmüștür. "Yönetici Desteği Ölçeği"nden alınan puanların ortalaması ise 3,12 ile orta düzeydedir.

Tablo 1. Tanımlayıcı İstatistikler

\begin{tabular}{|l|l|l|l|l|l|}
\hline & N & Min. & Maks. & Ort. & Std. Sapma \\
\hline Yönetici Desteği & 224 & 1,00 & 5,00 & 3,1235 & 1,00 \\
\hline Psikolojik Sözleşmenin İçeriği & 224 & 1,00 & 4,00 & 2,3173 & 0,62 \\
\hline Psikolojik Sözleşmenin Yerine Getirilmesi & 224 & 1,00 & 4,00 & 2,2872 & 0,58 \\
\hline
\end{tabular}

\subsection{Veri Toplama Araçlarının Geçerlilik ve Güvenilirlik Bulguları}

Veri toplama araçlarının geçerlilik ve güvenilirliklerini değerlendirmek üzere keşfedici faktör analizi yapılmış ve Cronbach $\alpha$ değerleri incelenmiştir.

Tablo 2. Yönetici Desteği Ölçeği'nin Keşfedici Faktör Analizi Sonuçları ve Güvenilirlik

\begin{tabular}{|l|l|l|}
\hline \multicolumn{1}{|c}{ Değerleri } & Faktör Yükleri & Cronbach $\boldsymbol{\alpha}$ \\
\hline Maddeler & 0,869 & 0,961 \\
\hline YD1 & 0,892 & \\
\hline YD2 & 0,793 & \\
\hline YD3 & 0,877 & \\
\hline YD4 & 0,884 & \\
\hline YD5 & 0,882 & \\
\hline YD6 & 0,836 & \\
\hline YD7 & 0,922 & \\
\hline YD8 & 0,898 & \\
\hline YD9 & \multicolumn{2}{|l|}{} \\
\hline Toplam varyansı açıklama oranı=\%76,27 & \multicolumn{2}{|l|}{} \\
\hline KM0 değeri= 0,925 & \multicolumn{2}{l|}{} \\
\hline $\begin{array}{l}\text { Barlett Testi sonucu Ki-kare=2214,490 sd=36 p }=0,000 \\
\text { YD: Yönetici Desteği }\end{array}$ &
\end{tabular}

Tablo 2'de Yönetici Desteği Ölçeği'nin keşfedici faktör analizi sonuçları ve güvenilirlik değerleri görülmektedir. Faktör yüklerinin 0,922 ile 0,793 arasında değiștiği ve toplam varyansı açıklama oranının \%76,27 olduğu belirlenmiştir. Ölçeğin güvenilirlik düzeyinin 0,961 ile oldukça yüksek olduğu belirlenmiştir. 
Merve Gerçek, Sevgi Elmas-Atay, "Algılanan Yönetici Desteğinin Psikolojik Sözleşmenin İçeriği ve Yerine Getirilmesi Üzerindeki Etkileri”, İstanbul Gelişim Üniversitesi Sosyal Bilimler Dergisi, 8 (2), Ekim 2021, ss. 268-281.

Tablo 3. Psikolojik Sözleşme İçeriği Ölçeği'nin Keşfedici Faktör Analizi Sonuçları ve Güvenilirlik Değerleri

\begin{tabular}{|c|c|c|}
\hline Maddeler & Faktör Yükleri & Cronbach $\alpha$ \\
\hline $\begin{array}{l}\text { Faktör 1: Ílişkisel Sözleşme (Varyansı açıklama oranı= \% } \\
31,386)\end{array}$ & & 0,848 \\
\hline PSİ12 & 0,782 & \\
\hline PSİ11 & 0,746 & \\
\hline PSİ10 & 0,715 & \\
\hline PSİ13 & 0,636 & \\
\hline PSI9 & 0,621 & \\
\hline PSÍ6 & 0,587 & \\
\hline PSİ8 & 0,586 & \\
\hline PSİ7 & 0,564 & \\
\hline $\begin{array}{l}\text { Faktör 2: Etkileşimsel Sözleșme (Varyansı açılama oranı= } \\
\% 20,003 \text { ) }\end{array}$ & & 0,784 \\
\hline PSİ3 & 0,807 & \\
\hline PSİ2 & 0,756 & \\
\hline PSİ5 & 0,747 & \\
\hline PSI4 & 0,639 & \\
\hline Toplam varyansı açıklama oranı=\%54,392 & & 0,878 \\
\hline \multicolumn{3}{|l|}{ KMO değeri $=0,843$} \\
\hline $\begin{array}{l}\text { Barlett Testi sonucu Ki-kare }=1113,865 \mathrm{sd}=66 \mathrm{p}=0,000 \\
\text { PSİ: Psikolojik Sözleşmenin İçeriği }\end{array}$ & & \\
\hline
\end{tabular}

Tablo 3'te Psikolojik Sözleşme İçeriği Ölçeği'nin keşfedici faktör analizi sonuçları görülmektedir. Psikolojik sözleşme içeriği, Guest ve Conway'in çalışmasında tek boyutlu olarak kullanılmıș ancak bu çalışmada, ilişkisel ve etkileşimsel sözleşme olmak üzere iki faktöre ayrıldığı görülmüştür. Bu ayrım, psikolojik sözleşmenin kuramsal altyapısıyla (Rousseau, 1990) ve yazındaki diğer ölçüm araçlarıyla aynı doğrultudadır (Jensen, Opland ve Ryan, 2010). Ölçeğin 1. maddesi çapraz yük nedeniyle analiz dışı bırakılmıştır (Şencan, 2005). İlişskisel sözleşme faktörünün madde yükleri 0,782 ile 0,564 arasında değișmekte ve güvenilirlik katsayısı 0,848'dir. Etkileșimsel sözleșme faktörünün madde yükleri 0,807 ile 0,639 arasında değişmekte ve güvenilirlik katsayısı 0,784 'tür. Ölçeğin geneli için güvenilirlik katsayısının 0,878 ile yüksek olduğu görülmektedir (Özdamar, 2016).

Tablo 4. Psikolojik Sözleşmenin Yerine Getirilmesi Ölçeği'nin Keşfedici Faktör Analizi Sonuçları ve Güvenilirlik Değerleri

\begin{tabular}{|l|c|c|}
\hline Maddeler & Faktör Yükleri & Cronbach $\boldsymbol{\alpha}$ \\
\hline $\begin{array}{l}\text { Faktör 1: Ilișkisel Sözleșme (Varyansı açıklama } \\
\text { oranı } \% \text { 32,926) }\end{array}$ & & 0,873 \\
\hline PSY 11 & 0,796 & \\
\hline PSY 12 & 0,790 & \\
\hline PSY 13 & 0,701 & \\
\hline PSY 10 & 0,685 & \\
\hline PSY 7 & 0,666 & \\
\hline PSY 9 & 0,623 & 0,774 \\
\hline PSY 8 & 0,522 & \\
\hline PSY 6 & 0,521 & \\
\hline $\begin{array}{l}\text { Faktör 2: Etkileșimsel Sözleşme (Varyansı açıklama } \\
\text { oranı } \% \text { 24,596) }\end{array}$ & & \\
\hline PSY3 & 0,800 & \\
\hline PSY5 & 0,712 & \\
\hline PSY2 & 0,680 & \\
\hline
\end{tabular}


Merve Gerçek, Sevgi Elmas-Atay, “Algılanan Yönetici Desteğinin Psikolojik Sözleşmenin İçeriği ve Yerine Getirilmesi Üzerindeki Etkileri”, İstanbul Gelişim Üniversitesi Sosyal Bilimler Dergisi, 8 (2), Ekim 2021, ss. 268-281.

\begin{tabular}{|l|l|c|}
\hline PSY4 & \multicolumn{1}{|c|}{0,678} & \\
\hline Toplam varyansı açıklama oranı=\%57,522 & \multicolumn{1}{|c|}{0,894} \\
\hline KMO değeri=0,885 & & \\
\hline Barlett Testi sonucu Ki-kare=1252,479 sd=66 p=0,000 & \\
PSY: Psikolojik Sözleşmenin Yerine Getirilmesi & \\
\hline
\end{tabular}

Tablo 4'te Psikolojik Sözleşmenin Yerine Getirilmesi Ölçeği'nin keşfedici faktör analizi sonuçları görülmektedir. Ölçek ilişkisel ve etkileşimsel sözleşme olmak üzere iki faktöre ayrılmıştır. Ölçeğin 1. maddesi çapraz yük nedeniyle analiz dıșı bırakılmıștır (Şencan, 2005). İlişkisel sözleşme faktörünün madde yükleri 0,796 ile 0,521 arasında değişmekte ve güvenilirlik katsayısı 0,873'tür. Etkileşimsel sözleşme faktörünün madde yükleri 0,800 ile 0,678 arasında değișmekte ve güvenilirlik katsayısı 0,774'tür. Ölçeğin geneli için güvenilirlik katsayısının 0,894 ile yüksek olduğu görülmektedir (Özdamar, 2016).

\subsection{Korelasyon ve Regresyon Analizlerine İlișkin Bulgular}

Algllanan yönetici desteğinin, psikolojik sözleşmenin içeriği üzerindeki etkisini belirlemeye ilişkin yapılan basit doğrusal regresyon analizine yönelik tablo aşağıda sunulmuştur.

Tablo 5. Yönetici Desteğinin Psikolojik Sözleşmenin İçeriği Üzerindeki Etkisine Yönelik Basit Doğrusal Regresyon Analizi

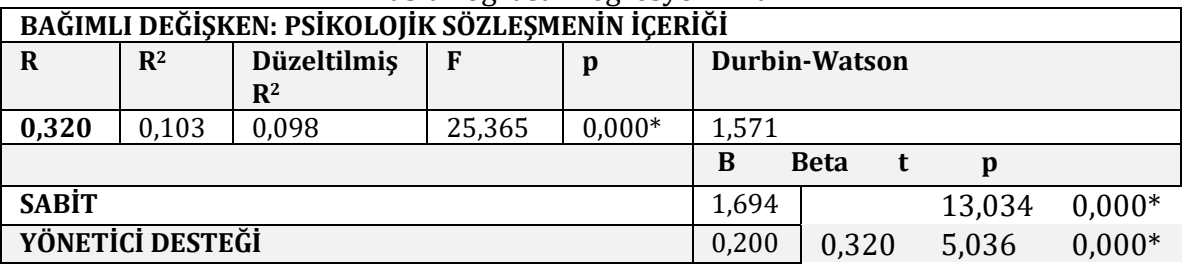

Tablo incelendiğinde algılanan yönetici desteğinin psikolojik sözleşmenin içeriği üzerinde anlaml ve pozitif yönde bir etkisi olduğu görülmektedir $(B=0,200$; $p=0,000<0,05)$. Bu doğrultuda algılanan yönetici desteğinin psikolojik sözleşmenin içeriği üzerinde \%10,3'lük bir etkiye sahip olduğu söylenebilir. Bu bulgular doğrultusunda, $\mathrm{H}_{1}$ hipotezi kabul edilmiștir.

Yöneticinin algılanan desteğinin psikolojik sözleşmenin yerine getirilmesi üzerindeki etkisini belirlemek için yapılan basit doğrusal regresyon analizine ilişkin tablo aşağıda gösterilmiștir.

Tablo 6. Yönetici Desteğinin Psikolojik Sözleșmenin Yerine Getirilmesi Üzerindeki Etkisine Yönelik Basit Doğrusal Regresyon Analizi

\begin{tabular}{|c|c|c|c|c|c|c|c|c|}
\hline \multicolumn{9}{|c|}{ BAĞIMLI DEĞISTKEN: PSİKOLOJİK SÖZLEȘMENİN YERİNE GETİRILMESİ } \\
\hline $\mathbf{R}$ & $\mathbf{R}^{2}$ & $\begin{array}{l}\text { Düzeltilmiş } \\
\mathbf{R}^{2}\end{array}$ & $\mathbf{F}$ & $\mathbf{p}$ & \multicolumn{4}{|c|}{ Durbin-Watson } \\
\hline 0,467 & 0,218 & 0,214 & 61,856 & $0,000^{*}$ & \multicolumn{4}{|l|}{1,931} \\
\hline \multirow{2}{*}{\multicolumn{5}{|c|}{ SARIT }} & \multicolumn{4}{|c|}{ Beta } \\
\hline & & & & & 1,445 & & 12,838 & $0,000^{*}$ \\
\hline \multicolumn{5}{|c|}{ YÖNETICII DESTEĞİ } & 0,270 & 0,034 & 7,865 & $0,000^{*}$ \\
\hline
\end{tabular}


Yapılan analizde algılanan yönetici desteğinin psikolojik sözleşmenin içeriği üzerinde anlamlı ve pozitif yönde bir etkisi olduğu görülmektedir $(B=0,270$; $\mathrm{p}=0,000<0,05)$. Tabloda görüldügü üzere algılanan yönetici desteğinin psikolojik sözleşmenin içeriği üzerinde \%21,8'lik bir etkiye sahiptir. Söz konusu bulgulara göre, $\mathrm{H}_{2}$ hipotezi kabul edilmiștir.

\section{SONUÇ}

Psikolojik Sözleşme Kuramı, örgütsel politikalar, prosedürler, uygulamalar ve yöneticilerin çalışanlara yönelik tutum ve davranışlarının, çalışanların örgütün vaatte bulunma ve bu vaatleri yerine getirme düzeylerine yönelik algılarını şekillendirdiğini varsaymaktadır. Bu varsayıma dayanarak, yöneticilerin çalışanların çabalarına ve iyi oluş haline ilişkin ilgili olma halini ifade eden yönetici desteğinin, psikolojik sözleșme içeriği ve yerine getirilme düzeyini etkileyip etkilemediği incelenmiştir.

Psikolojik sözleșmenin içeriği, örgüte ve örgütün çalıșanlarıyla arasındaki etkileşim türlerine göre değișen bir olgudur. Her örgüt, iş çevresi, örgüt yapısı, iş yapış kültürü ve süreçleri bağlamında çalışanlarına neler vaat edebileceğine ilişkin açık veya örtük mesajlar göndermektedir. Bu mesajları doğrudan yazılı veya sözlü olarak basılı kaynaklarla olduğu gibi yöneticiler aracıllğıyla da iletebilmektedir. Dolayısıyla, örgüt ve çalışan arasındaki iş ilişkisinin doğası bağlama göre farklılaşabildiği için, bu ilișkinin bir yansıması olan psikolojik sözleșmenin içeriği de farklılaşmaktadır. Bu farklılaşmada etkin rol oynayan aktörlerin başında ise yöneticiler gelmektedir.

Yöneticiler, çalışanlara ilişkin kararlarda doğrudan etkili oldukları için çalışanların örgüt hakkındaki görüşlerinde şekillendirici konumdadırlar. Özellikle kariyer ve performans gibi alanlarda kritik karar alıcı rolünü üstlenen yöneticiler, sergiledikleri davranışlar yoluyla çalışanların örgütsel güven ve adalet algıları üzerinde etkilidirler (DeConink ve Johnson, 2010). Örgütsel güven ve adalet algılarında bozulmalar yaşanması ise örgütün vaatlerini yerine getirmediği algılandığı zaman ortaya çıkmakta ve psikolojik sözleşmenin yerine getirilmemesine neden olmaktadır. Örgütsel adalet ve güvenin psikolojik sözleşme süreciyle ilişkili olduğu söylenebilir (Restuborg, Bordia ve Bordia, 2009; Cassar ve Buttigieg, 2015). Bu bakış açısıyla yöneticilerin destekleyici tutumlarının psikolojik sözleşmeler üzerinde olumlu etkileri olacağı öngörülmüştür.

Araştırmanın bulgularına göre, katılımcıların algılanan yönetici desteği, psikolojik sözleşme içeriği ve yerine getirilmesine ilişkin orta düzeyde görüşlere sahip olduğu görülmüştür. Katılımcılar, psikolojik sözleșme bağlamında iş güvencesi, eğitim ve geliștirme, kariyer olanakları gibi unsurların vaat edilme ve bu vaatlerin yerine getirilme düzeylerinin orta derecede olduğunu ifade etmişlerdir. Algılanan yönetici desteğinin psikolojik sözleşmenin içeriği üzerinde olumlu ancak zayıf düzeyde etkili olduğu görülmüştür. Bu bulguya dayanarak, yönetici desteğinin çalışanlar tarafından algılanışı arttıkça, psikolojik sözleșmenin içeriğini oluşturan unsurların örgüt tarafından vaat edilmiş olduğuna ilişsin algıların da artacağı söylenebilir. Yönetici desteği, çalışanyönetici ilişkisinin bir parçası olarak örgütsel vaatlerin çalışanlara aktarımında önemli bir mesaj kanalı olarak görülebilir (Suazo, Turnley ve Mai-Dalton, 2008).

Araştırma sonuçları algılanan yönetici desteğinin, psikolojik sözleşmenin yerine getirilme düzeyi üzerinde olumlu ve zayıf etkileri olduğunu ortaya koymuștur. Algılanan yönetici desteği arttıkça, örgütsel yükümlülüklerin yerine getirilme düzeyine ilişkin daha olumlu algılar geliştiği söylenebilir. Böylece, yönetici desteğinin psikolojik sözleşmenin oluşumu ve sürdürülmesinde etkili olduğu yorumu yapılabilir. Bulguların, psikolojik sözleşmenin yerine getirilmesinin yönetici desteği ile ilişkili diğer çalışmalarla benzerlik gösterdiği söylenebilir (Eisenberger, Stinglehaumber, Vandenberghe, Scharski ve Rhoades, 2002; Hutchison, 1997). 
Bu çalışma, veri toplama araçları ve katılımcıların verdiği yanıtlarla sınırlıdır. Araştırma sonuçlarının, yönetici desteğinin psikolojik sözleşmenin içeriği ve yerine getirilmesi üzerinde olumlu ve zayıf etkileri olduğunu göstermiş olması, farklı değişkenlerin bu süreçlerde etkili olduğunu düşündürmektedir. Özellikle psikolojik sözleşmenin içeriğinin oluşumunda, işveren markası gibi sözleşme öncesi rol oynayan değișkenlerin yeni araștırma modellerine dâhil edilmesi önerilebilir. Psikolojik sözleșmenin yerine getirilmesinde yönetici desteğine ek olarak, lider-üye etkileșimi ile bağlantılar kurulabilir. $\mathrm{Bu}$ çalışmanın genişletilmiş ve sistematik bir örnekleme yöntemiyle yenilenmesi, yönetici desteği ve psikolojik sözleşmeler arasındaki ilişkinin daha açık şekilde ortaya koyulmasında etkili olabilir.

\section{KAYNAKÇA}

ALKHATERI, A. S., ABUELHASSAN, A. E., KHALIFA, G. S., NUSARI, M. ve AMEEN, A. (2018). The impact of perceived supervisor support on employees turnover intention: The mediating role of job satisfaction and affective organizational commitment. International Business Management, 12(7), 477-492.

ARGYRIS, C. (1960), Understanding organizational behavior. Homewood, IL: Dorsey Press.

ASELAGE, J. ve EISENBERGER, R. (2003). Perceived organizational support and psychological contracts: A theoretical integration. Journal of Organizational Behavior: The International Journal of Industrial, Occupational and Organizational Psychology and Behavior, 24(5), 491-509.

AYDIN GÖKTEPE, E., (2016). Yeni kariyer tutumlarl, algılanan yönetici desteği ve işe tutkunluk arasındaki iliş̧ki: bir araştırma. Yayımlanmamıș Doktora Tezi, Sosyal Bilimler Enstitüsü, İstanbul Üniversitesi.

BHATNAGAR, J. (2014). Mediator analysis in the management of innovation in Indian knowledge workers: the role of perceived supervisor support, psychological contract, reward and recognition and turnover intention. The International Journal of Human Resource Management, 25(10), 1395-1416.

BLAU, P. M. (1964). Justice in social exchange. Sociological Inquiry, 34(2), 193206.

BRINER, R. ve CONWAY, N. (2006). Protecting the psychological contract. Personnel Today, 21(11), 28-30.

CABLE, D. A. (2010). A methodological approach to developing a measure of the psychological contract for managers. The Australasian Journal of Organisational Psychology, 3, 21-31.

CASSAR, V. ve BUTTIGIEG, S. C. (2015). Psychological contract breach, organizational justice and emotional well-being. Personnel Review, 44(2), 217-235.

COYLE-SHAPIRO, J. A. M. ve KESSLER, I. (2002). Exploring reciprocity through the lens of the psychological contract: Employee and employer perspectives. European journal of work and organizational psychology, 11(1), 69-86.

DECONINCK, J. B. ve JOHNSON, J. T. (2009). The effects of perceived supervisor support, perceived organizational support, and organizational justice on turnover among salespeople. Journal of Personal Selling \& Sales Management, 29(4), 333-350.

EISENBERGER, R., STINGLEHAUMBER, F., VANDENBERGHE, C., SUCHARSKI, I.L. ve RHOADES, L. (2002). Perceived supervisor support: contributions to perceived organisational support and employee retention. Journal of Applied Psychology, 87(3), 565-603. 
Merve Gerçek, Sevgi Elmas-Atay, "Algılanan Yönetici Desteğinin Psikolojik Sözleşmenin İçeriği ve Yerine Getirilmesi Üzerindeki Etkileri”, İstanbul Gelişim Üniversitesi Sosyal Bilimler Dergisi, 8 (2), Ekim 2021, ss. $268-281$.

GERÇEK, M. (2018). Yöneticilerin babacan (paternalist) liderlik davranışlarının psikolojik sözleşme bağlamındaki beklentileri üzerindeki etkilerine yönelik bir çalışma. Eskişehir Osmangazi Üniversitesi İktisadi ve İdari Bilimler Dergisi, 13(2), 101-118.

GREENHAUS, J. H., PARASURAMAN, S. ve WORMLEY, W. M. (1990). Effects of race on organizational experiences, job performance evaluations, and career outcomes. Academy of Management Journal, 33(1), 64-86.

GUEST, D. E. ve CONWAY, N. (2002). Communicating the psychological contract: an employer perspective. Human Resource Management Journal, 12(2), 22-38.

HOMANS, G. C. (1974). Social behavior: Its elementary forms. New York: John Wiley.

HUTCHISON, S. (1997). A path model of perceived organisational support. Journal of Social Behaviour and Personality, 12, 159-174.

JENSEN, J. M., OPLAND, R. A. ve RYAN, A. M. (2010). Psychological contracts and counterproductive work behaviors: Employee responses to transactional and relational breach. Journal of Business and Psychology, 25(4), 555-568.

KARAGONLAR, G., EISENBERGER, R. ve ASELAGE, J. (2016). Reciprocation wary employees discount psychological contract fulfillment. Journal of Organizational Behavior, 37(1), 23-40.

KOTTER, J. P. (1973). The psychological contract: Managing the joining-up process. California Management Review, 15(3), 91-99.

LEVINSON, H., PRICE, C. R., MUNDEN, K. J., MANDL, H. J. ve SOLLEY, C. M. (1962). Men, management, and mental health, Cambridge, MA: Harvard University Press

MAERTZ JR, C. P., GRIFFETH, R. W., CAMPBELL, N. S.ve ALLEN, D. G. (2007). The effects of perceived organizational support and perceived supervisor support on employee turnover. Journal of Organizational Behavior: The International Journal of Industrial, Occupational and Organizational Psychology and Behavior, 28(8), 1059-1075. MCDERMOTT, A. M., CONWAY, E., ROUSSEAU, D. M. ve FLOOD, P. C. (2013). Promoting effective psychological contracts through leadership: The missing link between HR strategy and performance. Human Resource Management, 52(2), 289-310.

ÖZDAMAR, K. (2016). Eğitim, Sağlık ve Davranış Bilimlerinde Ölçek ve Test Geliştirme Yapısal Eşitlik Modellemesi. Nisan Kitabevi. Eskişehir.

PETERSITZKE, M. (2009). Supervisor psychological contract management. In Supervisor psychological contract management. Gabler. 131-142.

PORTWOOD, J. D. ve MILLER, E. L. (1976, August). Evaluating the Psychological Contract: Its Implications for Employee Job Satisfaction and Work Behavior. In Academy of Management Proceedings (Vol. 1976, No. 1). Briarcliff Manor, NY 10510: Academy of Management. 109-113.

RAMUS, C. A. ve STEGER, U. (2000). The roles of supervisory support behaviors and environmental policy in employee "ecoinitiatives" at leading-edge European companies. Academy of Management Journal, 43(4), 605-626.

RESTUBOG, S. L. D., BORDIA, P. ve BORDIA, S. (2009). The interactive effects of procedural justice and equity sensitivity in predicting responses to psychological contract breach: An interactionist perspective. Journal of Business and Psychology, 24(2), 165-178.

RHOADES, L. ve EISENBERGER, R. (2001). Affective commitment to the organization: The contribution of perceived organizational support. Journal of Applied Psychology, 86(5), 825-836.

RHOADES, L. ve EISENBERGER, R. (2002). Perceived organizational support: a review of the literature. Journal of Applied Psychology, 87(4), 698-714.

ROBINSON, S. L. (1996). Trust and breach of the psychological contract. Administrative Science Quarterly, 1996, 574-599. 
Merve Gerçek, Sevgi Elmas-Atay, "Algılanan Yönetici Desteğinin Psikolojik Sözleşmenin İçeriği ve Yerine Getirilmesi Üzerindeki Etkileri”, İstanbul Gelişim Üniversitesi Sosyal Bilimler Dergisi, 8 (2), Ekim 2021, ss. $268-281$.

ROBINSON, S. L. ve ROUSSEAU, D. M. (1994). Violating the psychological contract: Not the exception but the norm. Journal of Organizational Behavior, 15(3), 245-259.

ROUSSEAU, D. (1995). Psychological contracts in organizations: Understanding written and unwritten agreements. Sage publications.

ROUSSEAU, D. M. (1989). Psychological and implied contracts in organizations. Employee Responsibilities and Rights Journal, 2(2), 121-139.

ROUSSEAU, D. M. (1990). New hire perceptions of their own and their employer's obligations: A study of psychological contracts. Journal of Organizational Behavior, 11(5), 389-400.

SALIN, D. ve NOTELAERS, G. (2017). The effect of exposure to bullying on turnover intentions: the role of perceived psychological contract violation and benevolent behaviour. Work \& Stress, 31(4), 355-374.

SCHEIN, E.H., (1970). Organizational psychology, Engelwood Cliffs, NJ: Prentice Hall.

SHANOCK, L. R. ve EISENBERGER, R. (2006). When supervisors feel supported: Relationships with subordinates' perceived supervisor support, perceived organizational support, and performance. Journal of Applied Psychology, 91(3), 689-695.

SHOSS, M.K., EISENBERGER, R., RESTUBOG, S.L.D. ve ZAGENCZYK, T.J. (2013), Blaming the organization for abusive supervision: the roles of perceived organizational support and supervisor's organizational embodiment. Journal of Applied Psychology, 98(1), 158-168.

STURGES, J., CONWAY, N., GUEST, D. ve LIEFOOGHE, A. (2005). Managing the career deal: The psychological contract as a framework for understanding career management, organizational commitment and work behavior. Journal of Organizational Behavior: The International Journal of Industrial, Occupational and Organizational Psychology and Behavior, 26(7), 821-838.

SUAZO, M. M., TURNLEY, W. H. ve MAI-DALTON, R. R. (2008). Characteristics of the supervisor-subordinate relationship as predictors of psychological contract breach. Journal of Managerial Issues, 20(3), 295-312.

ŞENCAN, H. (2005). Sosyal ve davranışsal ölçümlerde güvenilirlik ve geçerlilik. Seçkin Yayıncılık.

TURNLEY, W. H. ve FELDMAN, D. C. (1999). The impact of psychological contract violations on exit, voice, loyalty, and neglect. Human Relations, 52(7), 895-922.

VANDENBERGHE, C., PANACCIO, A., BENTEIN, K., MIGNONAC, K., ROUSSEL, P. ve AYED, A. K. B. (2019). Time-based differences in the effects of positive and negative affectivity on perceived supervisor support and organizational commitment among newcomers. Journal of Organizational Behavior, 40(3), 264-281.

VISWESVARAN, C., SANCHEZ, J. I. \& FISHER, J. (1999). The role of social support in the process of work stress: A meta-analysis. Journal of Vocational Behavior, 54(2), 314 -334 .

ZAGENCZYK, T. J., GIBNEY, R., FEW, W. T. ve SCOTT, K. L. (2011). Psychological contracts and organizational identification: The mediating effect of perceived organizational support. Journal of Labor Research, 32(3), 254-281.

ZAGENCZYK, T. J., GIBNEY, R., KIEWITZ, C. ve RESTUBOG, S. L. D. (2009). Mentors, supervisors and role models: do they reduce the effects of psychological contract breach?. Human Resource Management Journal, 19(3), 237-259. 


\section{Summary}

The psychological contract is a concept used to explain the dynamics of the employment relationship between the employer and the employee. Although "psychological contract" is not used as a defined concept in the author's work, it was emphasized that there are some unspoken rules among the foremen and workers working in the production department. The fulfillment of the psychological contract refers to the degree of fulfillment of the organizational obligations for the employees. Failure to fulfill the psychological contract may indicate the existence of unfulfilled expectations for employees, indicating that inequality is perceived and organizational trust is reduced.

Organizational Support Theory suggests that employees develop general beliefs about the extent to which their organization values their contributions and well-being to meet their socio-emotional needs. It can be thought that the perceived organizational support emerged through the managers thanks to the managers who act as intermediaries in the evaluation of the employees of the organization. As a result, the support of the manager is stated to have a strong influence on the employee's perception of general organizational support. Perceived supervisor support is defined as employees' general belief that their supervisors value their contribution.

Managers have a shaping position in the opinions of the employees about the organization as they are directly effective in the decisions regarding the employees. Managers who play a critical decision-making role, especially in areas such as career and performance, have an impact on employees' organizational trust and justice perceptions through their behaviors. From this perspective, supportive attitudes of managers are expected to have positive effects on psychological contracts.

In this study, the effects of the perceived supervisory support on the content and level of fulfillment of the psychological contract were investigated. The supervisor is considered as an actor who plays an active role in the formation of the psychological contract as an organizational representative and contract creator. In line with this assumption, the supervisory support to the employee is foreseen to have a positive effect on the transfer of organizational obligations to the employees. 224 white-collar participants working in the private sector constitute the sample of the research.

In the research, a questionnaire form including scales related to the support of the manager, the content and fulfillment of the psychological contract was used as a data collection tool. In testing the research hypotheses, SPSS 21.0 software, Pearson Correlation Analysis and simple linear regression analysis were used.

According to the findings of the research, it was seen that the participants had moderate views on perceived supervisory support, the content of the psychological contract and its fulfillment. The participants stated that in the context of the psychological contract, obligations such as job security, education and development, career opportunities, and the level of promising and fulfilling these promises are moderate. It was seen that perceived supervisory support was positive but weakly effective on the content of the psychological contract. Supervisory support can be seen as an important message channel in transferring organizational promises to employees as part of the employee-manager relationship.

Research results also revealed that perceived supervisory support had positive and weak effects on the level of fulfillment of the psychological contract. As perceived supervisory support increases, it can be said that more positive perceptions regarding the level of fulfillment of organizational obligations develop. 